\begin{tabular}{|ll|}
\hline Received & $: 15$ Maret 2020 \\
Revised & $: 2$ April 2020 \\
Accepted & $: 20$ April 2020 \\
Online & $: 25$ April 2020 \\
Published & $: 30$ April 2020
\end{tabular}

\title{
Analisis Sifat Fisika dan Derajat Keasaman terhadap Kualitas Air Minum Isi Ulang 20 Rumah RW 01 di Kampung Cilember Desa Jogjogan Kecamatan Cisarua Kabupaten Bogor
}

\author{
Bina Permana ${ }^{1, \text { a) }}$, Devi Indrawati Syafei ${ }^{1}$, Hilman Syafei ${ }^{1}$, Okta Olifvia ${ }^{1}$, Novita Cahyani \\ Fitri $^{1}$, Neha Rendita Sundari ${ }^{1}$, Wildan Sahari ${ }^{1}$, Diliviva Venesia ${ }^{2}$, Alivia Nur Aini ${ }^{2}$, Brigita
} Olivia Gamellia ${ }^{2}$, Katipah $^{3}$, Muhammad Arif ${ }^{4}$, Aprillia Anggraani ${ }^{5}$

\author{
${ }^{1}$ Program Studi Kimia, Universitas Negeri Jakarta \\ ${ }^{2}$ Program Studi Pendidikan Kimia, Universitas Negeri Jakarta \\ ${ }^{3}$ Program Studi Pendidikan Biologi, Universitas Negeri Jakarta \\ ${ }^{4}$ Program Studi Fisika, Universitas Negeri Jakarta \\ ${ }^{5}$ Program Studi Pendidikan Bahasa Inggris, Universitas Negeri Jakarta
}

: a)binapermana8896@gmail.com

\begin{abstract}
Water is the second natural resource that plays a very important role in life after air, one of its most important roles is to be consumed. However, it is still often found people who are less concerned with their knowledge of drinking water quality, especially refill drinking water consumed. This research was conducted with the aim to analyze the quality of drinking water refill several houses in RW 01 Kampung Cilember Jogjogan Village Cisarua District Bogor Regency on the results of physical properties and acidity degrees. The research method used to take drinking water samples is a combined place or sample sampling method, there are 20 houses of people who take water samples to be measured physically (color, odor, taste, TDS, and temperature) and chemically ( $\mathrm{pH}$ or acidity degree). Based on the test results, there were 5 houses that met the refill drinking water quality standards of the 20 houses that were tested. This can be seen from the standard parameters that apply with a $\mathrm{pH}$ range between 6.5-8.5, average TDS 600-900 ppm, temperature $\pm 3^{\circ} \mathrm{C}$ air temperature, and do not have odor, taste, and pigment.
\end{abstract}

Keywords: Refilled Water, Ph, Physical Properties, Chemical Properties, TDS.

\begin{abstract}
Abstrak
Air merupakan sumber daya alam kedua yang berperan sangat penting dalam kehidupan setelah udara, salah satu peran terpentingnya adalah untuk dikonsumsi. Namun, masih sering ditemukan masyarakat yang kurang peduli dengan pengetahuannya terhadap kualitas air minum khususnya air minum isi ulang yang dikonsumsi. Penelitian ini dilakukan dengan tujuan untuk menganalisis kualitas air minum isi ulang beberapa Rumah di RW 01 Kampung Cilember Desa Jogjogan Kecamatan Cisarua Kabupaten Bogor terhadap hasil uji sifat fisika dan derajat keasamannya. Metode penelitian yang digunakan untuk mengambil sampel air minum adalah metode sampel gabungan tempat atau integrated sampel, terdapat 20 rumah warga dilakukan pengambilan sampel air untuk diukur kualitas secara fisika (warna, bau, rasa, TDS dan suhu) dan secara kimia (pH atau derajat keasaman). Berdasarkan hasil pengujian, terdapat 5 rumah yang memenuhi standar kualitas air minum isi ulang dari 20 rumah warga yang diuji. Hal tersebut dapat dilihat dari parameter standar yang berlaku dengan kisaran $\mathrm{pH}$ antara 6,5-8,5, TDS rata-rata $600-900 \mathrm{ppm}$, suhu $\pm 3^{\circ} \mathrm{C}$ suhu udara, serta tidak memiliki bau, rasa, dan warna.
\end{abstract}

Kata-kata kunci: Air Minum Isi Ulang, PH, Sifat Fisika, Sifat Kimia, TDS. 


\section{PENDAHULUAN}

Air merupakan sumber daya alam yang berperan penting dalam kehidupan setelah udara, salah satu peran terpentingnya adalah untuk dikonsumsi. Secara umum, air dapat dibedakan menjadi air tanah dan air permukaan. Air tanah yang memiliki proses penyaringan melalui akifer biasanya akan lebih bersih dari air permukaan. Sementara itu air permukaan lebih mudah tercemar daripada air tanah, hal ini disebabkan karena yang akan lebih mudah tercemar/terkontaminasi dari sumber pencemaran seperti sampah dan air limbah adalah air permukaan. Air permukaan biasanya juga mengandung berbagai jenis organisme. Makrokospik dan bakteri merupakan salah satu organisme yang mungkin terdapat di dalam air (Suripin, 2001). Menurut Peraturan Menteri Kesehatan Republik Indonesia nomor 492 tahun 2010, air minum merupakan air yang melalui proses-proses tertentu untuk memenuhi syarat kesehatan dan juga dapat langsung diminum. Namun, saat ini masih banyak masyarakat umum yang belum mengetahui tentang standar kualitas air minum. Air minum merupakan air yang telah diuji kualitasnya, sehingga memenuhi standar syarat kesehatan dan juga dapat langsung diminum, syarat kesehatan yang dimaksud adalah mikrobiologi; kimia fisika dan radio aktif (Maria, 2016)

Dalam pengukuran derajat keasaman dan kualitas air minum agar bisa memenuhi standar air minum,maka dilakukan pemilihan parameter penting yang sesuai. Parameter pertama dalam pengukuran standar air minum adalah $\mathrm{pH}$ air minum yang merupakan parameter kimia. Nilai $\mathrm{pH}>7$ atau yang biasa disebut basa memberikan indikasi sifat korosi rendah. Hal ini disebabkan karena semakin rendah $\mathrm{pH}$ atau semakin asam suatu larutan, maka sifat korosinya akan semakin tinggi pula. Parameter selanjutnya yang digunakan adalah suhu, dimana suhu ini merupakan parameter fisika. Banyaknya bahan kimia yang terlarut dalam air akan menunjukan bahwa suhu air akan melebihi batas normal air biasa. Selain itu, dekomposisi bahan organik di dalam air akan menyebabkan suhu air lebih dari biasanya. Parameter yang terakhir adalah Total Dissolved Solid atau yang sering disingkat TDS. Parameter ini akan terlihat beberapa perubahannya seperti rasa, sehingga parameter ini adalah parameter fisik. TDS yang tinggi akan meningkatkan toksisitas organismenya. (Fauzi, 2016).

Berdasarkan pada permasalahan-permasalahan yang telah dijelaskan dan juga betapa pentingnya parameter-parameter itu, maka penelitian ini dilakukan untuk menganalisis sifat fisika dan derajat keasaman terhadap kualitas air minum isi ulang beberapa rumah di RW 01 Kampung Cilember Desa Jogjogan Kecamatan Cisarua Kabupaten Bogor sehingga dapat diketahui layak atau tidak untuk dikonsumsi sesuai dengan baku mutu yang ditetapkan.

\section{METODE}

Metode penelitian yang dilakukan untuk mengambil sampel air minum adalah metode sampel gabungan tempat atau integrated sampel (Hefni Effendi, 2003), karena sampel diambil secara terpisah dari beberapa tempat (rumah waga) pada waktu dan volume yang sama. Pada setiap rumah warga yang telah ditentukan, dilakukan pengambilan sampel air untuk diukur kualitas secara fisika (warna, bau, rasa, TDS dan suhu) dan secara kimia ( $\mathrm{pH}$ atau derajat keasaman). 


\section{HASIL DAN PEMBAHASAN}

TABEL 1. Hasil Pengukuran dan Pengamatan Sifat Fisika dan Derajat Keasaman Air Minum Isi Ulang 20 Rumah RW 01 Kampung Cilember, Bogor.

\begin{tabular}{|c|c|c|c|c|c|c|c|}
\hline $\begin{array}{l}\text { Nomor } \\
\text { Sampel }\end{array}$ & Warna & Bau & Rasa & Suhu $\left({ }^{\circ} \mathrm{C}\right)$ & TDS(ppm) & $\mathrm{pH}$ & Keterangan \\
\hline 1 & $\begin{array}{l}\text { Tidak } \\
\text { Berwarna }\end{array}$ & $\begin{array}{l}\text { Tidak } \\
\text { Berbau }\end{array}$ & Berasa & 27,2 & 780 & 6,8 & Tidak memenuhi standar \\
\hline 2 & $\begin{array}{l}\text { Tidak } \\
\text { Berwarna }\end{array}$ & $\begin{array}{l}\text { Tidak } \\
\text { Berbau }\end{array}$ & Berasa & 27,2 & 770 & 6,7 & Tidak memenuhi standar \\
\hline 3 & $\begin{array}{l}\text { Tidak } \\
\text { Berwarna }\end{array}$ & $\begin{array}{l}\text { Tidak } \\
\text { Berbau }\end{array}$ & $\begin{array}{l}\text { Tidak } \\
\text { Berasa }\end{array}$ & 27,2 & 850 & 6,4 & Tidak memenuhi standar \\
\hline 4. & $\begin{array}{l}\text { Tidak } \\
\text { Berwarna }\end{array}$ & $\begin{array}{l}\text { Tidak } \\
\text { Berbau }\end{array}$ & Berasa & 27,2 & 850 & 6,9 & Tidak memenuhi standar \\
\hline 5. & $\begin{array}{l}\text { Tidak } \\
\text { Berwarna }\end{array}$ & $\begin{array}{l}\text { Tidak } \\
\text { Berbau }\end{array}$ & Berasa & 27,2 & 390 & 6,7 & Tidak memenuhi standar \\
\hline 6. & $\begin{array}{l}\text { Tidak } \\
\text { Berwarna }\end{array}$ & $\begin{array}{l}\text { Tidak } \\
\text { Berbau }\end{array}$ & $\begin{array}{l}\text { Tidak } \\
\text { Berasa }\end{array}$ & 26,6 & 1040 & 7,0 & Tidak memenuhi standar \\
\hline 7. & $\begin{array}{l}\text { Tidak } \\
\text { Berwarna }\end{array}$ & $\begin{array}{l}\text { Tidak } \\
\text { Berbau }\end{array}$ & $\begin{array}{l}\text { Tidak } \\
\text { Berasa }\end{array}$ & 26,9 & 900 & 7,0 & Memenuhi standar \\
\hline 8. & $\begin{array}{l}\text { Sedikit } \\
\text { Keruh }\end{array}$ & $\begin{array}{l}\text { Tidak } \\
\text { Berbau }\end{array}$ & Berasa & 27,2 & 980 & 6,9 & Tidak memenuhi standar \\
\hline 9. & $\begin{array}{l}\text { Tidak } \\
\text { Berwarna }\end{array}$ & $\begin{array}{l}\text { Tidak } \\
\text { Berbau }\end{array}$ & $\begin{array}{l}\text { Tidak } \\
\text { Berasa }\end{array}$ & 27,6 & 810 & 6,9 & Memenuhi standar \\
\hline 10. & $\begin{array}{l}\text { Tidak } \\
\text { Berwarna }\end{array}$ & $\begin{array}{l}\text { Tidak } \\
\text { Berbau }\end{array}$ & $\begin{array}{l}\text { Tidak } \\
\text { Berasa }\end{array}$ & 27,2 & 730 & 6,7 & Memenuhi standar \\
\hline 11. & $\begin{array}{l}\text { Tidak } \\
\text { Berwarna }\end{array}$ & $\begin{array}{l}\text { Tidak } \\
\text { Berbau }\end{array}$ & Berasa & 26,6 & 700 & 6,3 & Tidak memenuhi standar \\
\hline 12. & $\begin{array}{l}\text { Tidak } \\
\text { Berwarna }\end{array}$ & $\begin{array}{l}\text { Tidak } \\
\text { Berbau }\end{array}$ & $\begin{array}{l}\text { Tidak } \\
\text { Berasa }\end{array}$ & 26,9 & 840 & 6,6 & Memenuhi standar \\
\hline 13. & $\begin{array}{l}\text { Tidak } \\
\text { Berwarna }\end{array}$ & $\begin{array}{l}\text { Tidak } \\
\text { Berbau }\end{array}$ & $\begin{array}{l}\text { Tidak } \\
\text { Berasa }\end{array}$ & 27,6 & 2500 & 7,3 & Tidak memenuhi standar \\
\hline 14. & $\begin{array}{l}\text { Tidak } \\
\text { Berwarna }\end{array}$ & $\begin{array}{l}\text { Tidak } \\
\text { Berbau }\end{array}$ & $\begin{array}{l}\text { Tidak } \\
\text { Berasa }\end{array}$ & 27,2 & 610 & 6,4 & Tidak memenuhi standar \\
\hline 15. & $\begin{array}{l}\text { Tidak } \\
\text { Berwarna }\end{array}$ & $\begin{array}{l}\text { Tidak } \\
\text { Berbau }\end{array}$ & $\begin{array}{l}\text { Tidak } \\
\text { Berasa }\end{array}$ & 26,2 & 1040 & 6,8 & Tidak memenuhi standar \\
\hline 16. & $\begin{array}{l}\text { Tidak } \\
\text { Berwarna }\end{array}$ & $\begin{array}{l}\text { Tidak } \\
\text { Berbau }\end{array}$ & $\begin{array}{l}\text { Tidak } \\
\text { Berasa }\end{array}$ & 27,6 & 980 & 6,4 & Tidak memenuhi standar \\
\hline 17. & $\begin{array}{l}\text { Tidak } \\
\text { Berwarna }\end{array}$ & $\begin{array}{l}\text { Tidak } \\
\text { Berbau }\end{array}$ & Berasa & 26,6 & 810 & 6,3 & Tidak memenuhi standar \\
\hline 18. & $\begin{array}{l}\text { Tidak } \\
\text { Berwarna }\end{array}$ & $\begin{array}{l}\text { Tidak } \\
\text { Berbau }\end{array}$ & $\begin{array}{l}\text { Tidak } \\
\text { Berasa }\end{array}$ & 27,2 & 780 & 6,0 & Tidak memenuhi standar \\
\hline 19. & $\begin{array}{l}\text { Tidak } \\
\text { Berwarna }\end{array}$ & $\begin{array}{l}\text { Tidak } \\
\text { Berbau }\end{array}$ & $\begin{array}{l}\text { Tidak } \\
\text { Berasa }\end{array}$ & 26,6 & 750 & 6,7 & Memenuhi standar \\
\hline 20. & $\begin{array}{l}\text { Tidak } \\
\text { Berwarna }\end{array}$ & $\begin{array}{l}\text { Tidak } \\
\text { Berbau }\end{array}$ & $\begin{array}{l}\text { Tidak } \\
\text { Berasa }\end{array}$ & 27,2 & 840 & 5,9 & Tidak memenuhi standar \\
\hline
\end{tabular}


Tabel 1 merupakan hasil pengukuran dan pengamatan kualitas air minum isi ulang (20 sampel) yang berasal dari rumah-rumah warga di RW 01 Kampung Cilember Desa Jogjogan Kecamatan Cisarua Kabupaten Bogor dilihat dari sifat fisika dan juga sifat kimianya. Berdasarkan tabel di atas, hasil pengukuran dan pengamatan air minum isi ulang (20 sampel) yang berasal dari rumah-rumah warga, menunjukkan bahwa hanya terdapat 5 rumah dengan air minum yang memenuhi standar berdasarkan 492/MENKES/PER/IV/2010 Republik Indonesia.

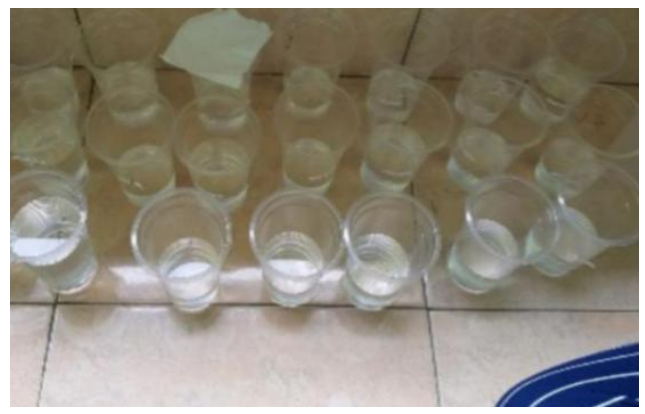

GAMBAR 1. Hasil Pengukuran dan Pengamatan Air Minum Isi Ulang 20 Rumah RW 01 Kampung Cilember, Bogor.

Peraturan Menteri Kesehatan Republik Indonesia No. 492/MENKES/PER/IV/ 2010 menjelaskan bahwa air minum telah dikatakan aman jika air minum tersebut memenuhi standar persyaratan kesehatan dilihat dari kualitasnya secara fisika maupun secara kimia. Air minum yang memenuhi standar secara sifat fisika bersifat tidak berwarna, tidak berbau, tidak berasa dan jernih. Air minum isi ulang yang telah dilakukan proses penyaringan selama beberapa saat akan menghilangkan bau dan rasanya. Suhu yang telah terukur dengan termometer dari masing-masing sampel rumah masih berada dibawah kualitas standar dimana suhu yang diperbolehkan adalah $\pm 3^{\circ} \mathrm{C}$ suhu udara. Kondisi suhu sekitar lingkungan wilayah yang telah diteliti adalah $27^{\circ} \mathrm{C}$. Sehingga, suhu air yang memenuhi standar ada pada rentang $24^{\circ} \mathrm{C}-30^{\circ} \mathrm{C}$. Berdasarkan hasil penelitian, suhu air berkisar antara $26,2^{\circ} \mathrm{C}-27,6^{\circ} \mathrm{C}$ yang telah memenuhi ketentuan peraturan. Jumlah dari oksigen terlarut dipengaruhi oleh suhu air. Suhu mengindikasikan kadar oksigen yang terkandung di dalam air. Suhu air yang melebihi batas normal berarti terdapat kandungan bahan kimia cukup besar didalamnya atau terjadi penguraian jasad renik (Yusuf, 2012).

Berdasarkan hasil pengukuran TDS di 20 rumah RW 01 Kampung Cilember menunjukkan bahwa terdapat 15 rumah yang memenuhi standar WHO/2003 dimana TDS (total dissolved solid) Standar Kualitas Air adalah sekitar 600-900 ppm untuk rata-rata, sedangkan 300-600 ppm adalah baik, dan kurang dari 300 ppm adalah sangat baik, serta dalam peraturan Menteri Kesehatan Republik Indonesia Nomor 492/MENKES/PER/IV/2010 adalah $500 \mathrm{mg} / \mathrm{L}$. Kesadahan air akan bertambah bila TDS bertambah pula. Konsentrasi TDS (Total Dissolved Solid) berpengaruh terhadap kejernihan air, warna, dan rasa. (Mukti, 2008).

Penentuan tingkat keasaman $(\mathrm{pH})$ air minum isi ulang dilakukan dengan pengukuran menggunakan $\mathrm{pH}$ meter yang sebelumnya telah dikalibrasi menggunakan larutan standar berupa larutan buffer dengan $\mathrm{pH}$ 6,8. Tujuan kalibrasi ini adalah untuk memberikan kebenaran/keakuratan penunjukkan alat dan bahan ukur. Dari hasil pengukuran derajat keasaman $(\mathrm{pH})$ yang telah dilakukan hanya terdapat 13 sampel sesuai dengan standar yang ditetapkan oleh peraturan Menteri Kesehatan Republik Indonesia yaitu 6,50 - 8,50. Konsentrasi/aktivitas ion hidrogen $\left(\mathrm{H}^{+}\right)$yang terlarut merupakan nilai yang dapat ditunjukkan dengan derajat keasaman atau Power of Hydrogen $(\mathrm{pH})$. Nilai $\mathrm{pH}$ dipengaruhi oleh beberapa parameter, antara lain aktivitas biologi, suhu, kandungan oksigen dan ion-ion. $\mathrm{pH}<6,5$ akan menyebabkan korosi pada metal (misalnya pipa saluran air minum) yang melarutkan unsur-unsur timbal, tembaga, kadmium, dan lain-lain dan ini bersifat racun.. Demikian pula jika $\mathrm{pH}$ > 8,5 dapat membentuk endapan (kerak) pada pipa air yang terbuat dari metal yang kemudian menghasilkan trihalomethane yang bersifat racun (Sudadi, 2003). 


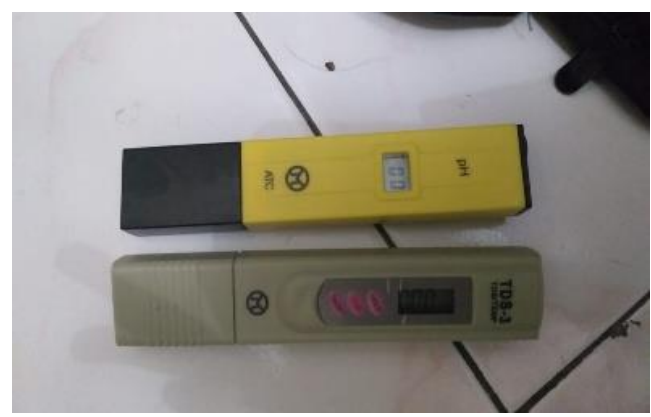

GAMBAR 2. Alat TDS Meter dan $\mathrm{pH}$ Meter

\section{PENUTUP}

Berdasarkan data-data yang diperoleh dari penelitian ini, dapat diambil suatu kesimpulan bahwa kualitas air minum isi ulang 20 rumah warga di Kampung Cilember, Desa Jogjogan, Kecamatan Cisarua, Kabupaten Bogor, Jawa Barat tidak semuanya memenuhi standar air minum yang ditetapkan oleh peraturan Kementrian Kesehatan Republik Indonesia nomor 492/MENKES/PER/IV/ /2010. Terdapat 5 rumah yang memenuhi standar kualitas air minum isi ulang dari 20 rumah warga yang diuji. Hal tersebut dapat dilihat dari parameter standar yang berlaku dengan kisaran $\mathrm{pH}$ antara 6,5-8,5, TDS rata-rata $600-900 \mathrm{ppm}$, suhu $\pm 3^{\circ} \mathrm{C}$ suhu udara, serta tidak memiliki bau, rasa, dan warna.

\section{UCAPAN TERIMAKASIH}

Ucapan terimakasih ditujukan kepada semua pihak yang terlibat dalam penelitian ini, khususnya kepada bapak RW dan warga RW 01 Kampung Cilember Desa Jogjogan Kecamatan Cisarua Kabupaten Bogor serta semua anggota KPM Universitas Negeri Jakarta, sehingga penelitian ini bisa selesai dengan baik, lancar, dan sukses.

\section{REFERENSI}

Amani, Fauzi dan Prawiroredjo, Kiki. (2016). Alat Ukur Kualitas Air Minum dengan Parameter pH, Suhu, Tingkat Kekeruhan dan Jumlah Padatan Terlarut. Jurnal Ilmiah Teknik Elektro, 14(1): 49-62.

Azwir. (2006). Analisis Pencemaran Air Sungai Tapung Kiri oleh Limbah Pabrik Kelapa Sawit PT. Peputra Masterindo di Kabupaten Kampar. Tesis, MIL Undip.

Effendi,H.(2003).Telaah Kualitas Air Bagi Pengeloloaan Sumber Daya Dan Lingkungan Perairan. Yogyakarta: Kanisius

Keputusan Menteri Kesehatan Republik Indonesia Nomor 492/MENKES/PER/IV/2010 Tentang Persyaratan Kualitas Air Minum.

Krisyanella Dkk. (2010). Penentuan Kadar Beberapa Mineral dan Keasaman Serta Uji Bakteriologi dari Beberapa Air Minum Isi Ulang di Siteba Kota Padang. Jurnal Farmasi Higea, 2(2).

Maria, R. W., And Margareth Sapulete, J. P. (2016). Gambaran Kualitas Air Minum dari Depot Air Minum Isi Ulang Di Kelurahan Ranotana-Weru dan Kelurahan Karombasan Selatan Menurut Parameter Mikrobiologi. Kedokteran Komunitas Dan Tropik, 4.

Mukti AM. (2008). Penggunaan Tanaman Eceng Gondok (Eichhorniacrassipes) sebagai Pre-Treatment Pengolahan Air Minum pada Air Selokan Mataram. Laporan Tugas Akhir, Universitas Islam Indonesia Jogjakarta.

Navis Mirza, Muhammad. (2014). Hygiene Sanitasi Dan Jumlah Coliform Air Minum. Jurnal Kesehatan Masyarakat, 9(2). 
Ningrum S O. (2018). Analisis Kualitas Badan Air Dan Kualitas Air Sumur. Jurnal Kesehatan Lingkungan, $10(1)$.

Pratiwi A W. (2007). Kualitas Bakteriologis Air Minum Isi Ulang Di Wilayah Kota Bogor. Jurnal Kesehatan Masyarakat Nasional, 2(2).

Santoso R dan Husni A. (2008). Sebaran TDS, DHL, Penurunan Muka Air Tanah dan Prediksi Instruisi Air Laut di Kota Tanggerang Selatan. Skripsi, Teknik Sipil dan Lingkungan IPB.

Soedibyo. (2003). Teknik Bendungan. Jakarta : Pradnya Paramita

Sosrodarsono, Suyono. (1983). Hidrologi Untuk Pengairan. Jakarta: Pradnya Paramita

Sudadi P. (2003). Penentuan Kualitas Air Tanah Melalui Analisis Unsur Kimia Terpilih. Buletin geologi tata lingkungan, 13(02): 81-89.

Suripin. (2001). Pelestarian Sumber Daya Tanah Dan Air. Yogyakarta: Andi.

Suryana, R. (2013). Analisis Kualitas Air Sumur Dangkal Di Kecamatan Biringkanayya Kota Makassar. Skripsi. Makassar: Jurusan Sipil Fakultas Teknik Universitas Hasanuddin. Tesis. Semarang: Program Magister Ilmu Lingkungan Program Pascasarjana Universitas Diponegoro.

Yusuf, Y. (2012). Teknologi Pengolahan Air Tanah Sebagai Sumber Air Minum Pada Skala Rumah Tangga. Jurnal Farmasi dan Sains, IV (02): 63-71. 